of 0.001 could, through high amplification of a photocell current, be instantaneously and accurately recorded. At the high dilutions which can in consequence be employed, the enzyme-substrate reactions proceed at rates which permit detailed analyses. The value and scope of this experimental technique in the field of reaction kinetics can scarcely be overestimqted.

Mechanical Engineering in Queensland :

Prof. Mansergh Shaw

THE appointment fo fr. Mansergh Shaw to the new chair of mechant th engineering in the University of Queensland, 1Kesbane, Australia, marks another important/st $p$ in an unusually successful engineering careof. It is interesting to note that, after serving a norm if engineering apprenticeship with Messrs. Davly Buthers, Prof. Shaw became an undergraduate at the University of Sheffield through the award of a Whitworth scholarship; he graduated in 1935 with first-class honours and was awarded the Mappin Medal. Thereafter he became a lecturer at the University of Sheffield and conducted research work on fluid flow through nozzles and on other subjects. $\mathrm{He}$ was appointed senior lecturer in engineering at the University of Melbourne in 1938, a position which he occupied with conspicuous success for some ten years under Prof. A. E. Burstall. During the War, in addition to undertaking special defence training duties, Shaw was responsible for organising the University workshops at Melbourne for research on new methods of production and on the precision manufacture of optical and other instruments required by the Australian Defence Forces. At the same time he was engaged upon new investigations of transient cutting forces and of factors affecting surface finish. This research is reflected in a number of published works on engineering production methods. On his return to England last year on extended leave, he was appointed as the first Tube Investments Research Fellow in engineering production in the University of Birmingham. Prof. Shaw has an important task awaiting his arrival at Brisbane, where he will have to build up a new Department of Mechanical Engineering. His wide experience of engineering practice, teaching and research, and his great energy and enthusiasm, augur well for the future progress of engineering education in Queensland.

\section{Kodak Research Laboratories}

ON March 25 and 26 a conversazione was held at the Research Laboratories of Kodak, Ltd., Harrow, to mark the twenty-first anniversary of their opening. The Laboratories were visited on March 25 by representatives of all fields of scientific interest, and on the following day by members of the six thousand factory and sales staff. The exhibits displayed the range of scientific endeavour of the Laboratories. A historical exhibit provided a reminder that the photographic industry has always been closely associated with scientific research, particularly since 1912 when Dr. C. E. K. Mees, now vice-president of the Eastman Kodak Company, left the old-established firm of Wratten and Wainwright to found and direct the research laboratories of the Eastman Kodak Company. The English branch of the organisation became an independent centre for research in 1928, when Dr. W. Clark set up the first Kodak, Ltd., Research Laboratory. Since 1931, Mr. E. R. Davies has been director of research.
In the fields of photographic physics and emulsion making, attention was directed to the application of photographic emulsions to the study of atomic phenomena. Photographs and drawings of tracks in emulsions were shown, which gave ample support to the claim that the photographic emulsion can now rival the cloud chamber as a nuclear research instrument. In another section a new instrument for the study of colour vision was shown. This has been designed particularly for the examination of adaptation phenomena, of paramount importance in the subjective aspects of colour photography. Examples of work in organic chemistry were to be seen in two sections. Sensitizing dyes continue to demand a considerable effort, while the chemistry of colour photography presents new problems. Some new and original apparatus was seen in the physical chemistry section, including a sensitive swell-recording device for studies of the physical properties of gelatin. In optics, war-time work on the resolving power of the lens-film system is being extended to cover the range of focal lengths in use in amateur and professional photography. The electron microscope has been added to the list of resources available for studying the fundamental problem of the latent image, and many properties of the individual silver halide grain have been shown for the first time. The applications of photography to science and industry were fully displayed. Some of the most interesting examples were those dealing with animal studies, such as the tongue action of reptiles, for which a high-speed stroboscopic light source has been designed.

\section{Ray Society: Annual General Meeting}

THE hundred and fifth annual general meeting of the Ray Society was held on March 18. The volume of Pennant's "Tour on the Continent 1865", edited by Prof. G. R. de Beer, was published and distributed during the past year, and it was announced that Prof. N. J. Berrill's volume on "Tunicates" had gone to press ; that the manuscript of the first volume of Messrs. Locket and Millidge's work on "British Spiders" had been received and had gone to tender, and that the manuscripts of the second volume of Prof. Balfour-Browne's "British Water-Beetles", of the late Prof. Tattersall's "British Mysidacea" and of Messrs. Dandy and Milne-Redhead's "Watsonian Vice-counties" were expected in the near future; and it was hoped that one or more of these volumes would also be published during 1949. It was pointed out that this programme of publication would put a serious strain on the Society's finances, and it was urged that every effort should be made- to increase the membership and to enlist other means of support. Prof. G. R. de Beer, Mr. A. C. Townsend and Dr. Errol White were re-elected president, honorary treasurer and honorary secretary respectively; Dr. Edward Hindle and Dr. John Smart were elected vice-presidents, and Dr. W. J. Rees, Mr. Herlihy, Mr. M. A. C. Hinton and Prof. F. E. Weiss new members of council.

\section{Nature of Plastics}

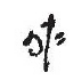

A NEW 16-mm. sound and colour film, "The Nature of Plastic awhich has been sponsored by Bakelite, Ltd., for the first time at the British Cotpd Theatre in London on April 5. The film, which runs for about 20 minutes, is a scientific documentary and is designed to explain to the intelligent layman the broad principles of the structural characteristics of plastics and their 